\title{
EMPERICL GRAPHS RELATING THE MAIN FACTORS AFFECTING A NUTRIENT-FILM SYSTEM
}

\author{
M. A. MOSALLAM(1), \\ M. E. SHETAWY (2), \\ R. R. EL-BESSOUMY ${ }^{(3)}$ and T. A. FATTAH ${ }^{(4)}$
}

\begin{abstract}
This study was carried out on a small-sized non-cultivated Nutrient-Film Technique "NFT". The main factors affecting non-cultivated NFT system were studied. These factors are: slope of the channel of the nutrient solution and discharge of the feeding pump (were taken as variables) and depth of the nutrient solution and speed of the nutrient solution (were measured). Two groups of graphs were plotted which may enable determining, under certain conditions, slope of the channel of the nutrient solution and speed of the nutrient solution in terms of a certain discharge of the feeding pump and a depth of the nutrient solution based on this study results as well as experience with the cultivated plant. This research needs subsequent studies on which the procedure of this research may be applied on cultivated NFT.
\end{abstract}

\section{INTRODUCTION}

7 his study aims to constructing empirical graphs by which, under certain depth of the nutrient solution and certain discharge of the

feeding pump, the slope of the channel of the nutrient solution and speed of the nutrient solution may be determined.

These graphs may be applied on a small-sized Nutrient-Film Technique "NFT" system by which experiments for cultivating plants are carried out.

\section{REVIEW OF LITERATURE}

Soo-Hyung et al. 1992 reported that: hydroponic researches are carried out inside growth chambers and these chambers are environmentally controlled. Cooper 1996, who invented the Nutrient-Film Technique "NFT" cultivation, reported that: increasing the slope of the channel of the nutrient solution is better for cultivating plants under NFT and there is no upper limit of this slope.

(1) Prof., Fac. of Agr. Eng., AL- Azhar univ., Cairo.

(2) Assoc. prof., Fac. of Agr. Eng., AL- Azhar univ., Cairo.

(3) Lecturer ,Fac. of Agr. Eng., AL- Azhar univ., Cairo.

(4) Assistant ,Fac. of Agr. Eng., AL- Azhar univ., Cairo. 
Spensley et al. 1979, Lynette 1999 and Carly 2011 found that slope of the channel of the nutrient solution must not be less than $1 \%$. Jenner $\boldsymbol{e t}$ al.(1980) mentioned that: the discharge of the feeding pump should not be less than $2 \mathrm{~L} / \mathrm{min}$ and this discharge depends on the size of the plant and intensity of cultivation. Graves and Hurd 1983, mentioned that: depth of the nutrient solution is $1-3 \mathrm{~mm}$.

\section{MATERRIALS AND METHODS}

This study aims to find empirical graphs that relate the main factors affecting the Nutrient-Film Technique. These factors are: depth of the nutrient solution, slope of the channel of the nutrient solution, speed of the nutrient solution and discharge of the pump.

To study the previously mentioned factors, A Nutrient-Film system "NFT" (Fig.1) was constructed. Size of the system is suitable such that it can be placed inside a growth chamber. This system is composed of a tilting apparatus, an inclined channel for the nutrient solution "NS", a pump, hoses and a reservoir. The tilting apparatus is composed of two wooden plates and a protractor. One of the two plates (plate A) is oriented horizontally and the other, plate $\mathrm{B}$, can be rotated (counter clockwise) around plate $\mathrm{A}$ to get the required angle by the protractor. A channel of width of $28 \mathrm{~cm}$ and length of one meter was fixed on the inclined plate B.

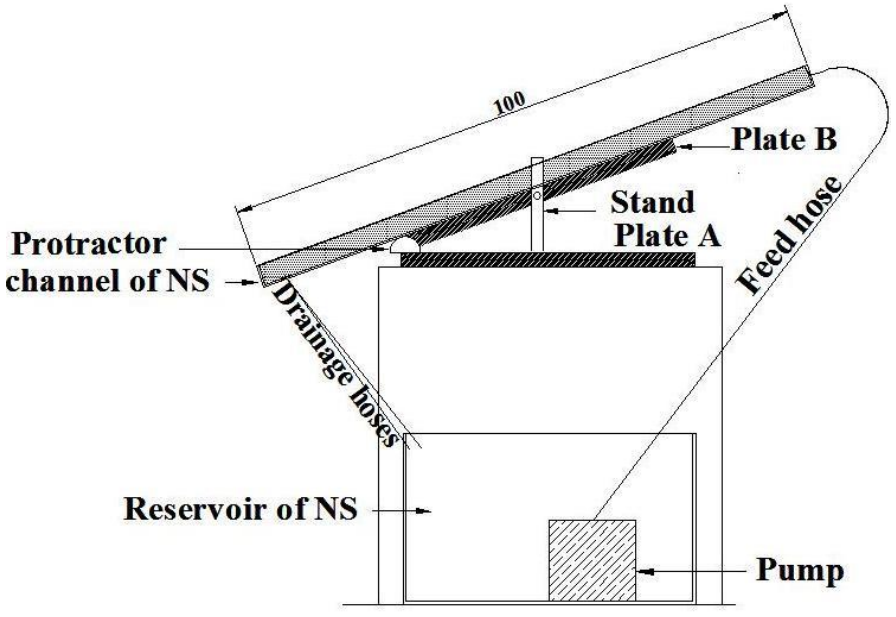

Dims. in cm

Fig.(1):The Tilting apparatus 
The Nutrient solution is to be forced through to the upper end of the channel from a reservoir by means of a pump and one hose while the drainage water from the channel is received through two hoses returned to the reservoir.

The study was carried out by choosing discharge of the pump and slope of the channel as variables. Three values were chosen for of the pump discharge variable. These values were: $1.75,2.25$ and $4.6 \mathrm{~L} / \mathrm{min}$.

Five values were chosen for of the slope. These values were: 5, 10, 15, 20 and $25 \%$. Each of the three discharges was tested with each of the five slopes so 15 experiments were carried out. Number of replicates of each experiment was two. For each certain discharge with a certain slope, each of the depth and speed was measured and recorded. Then two plots were constructed. The first plot relates depth of the nutrient solution (measured) with the slope of the channel (given) for the three tested discharges, so the first plot contains three curves. The second plot relates speed of the nutrient solution (measured) with the slope of the channel (given) for the three tested discharges, so the second plot contains three curves.

\section{RESULTS AND DISCUSSION}

The relation between the slope of the channel of the nutrient solution and the depth of the nutrient solution for the 3 tested discharges is shown in Fig.(2). As the slope increases, the depth decreases and for the same slope, as the discharge increases, the depth increases and range of the measured depths obtained for the 3 discharges is 0.8 - $3.2 \mathrm{~mm}$. Fig.(3) shows the relation between slope and speed of the nutrient solution for the 3 tested discharges. As the slope increases, the speed increases and for the same sloe, as the discharge increases, the speed increases and range of the measured speed obtained for the 3 discharges is $0.05-0.30 \mathrm{~m} / \mathrm{s}$. From the plot (Fig.2) which represents the relation between slope and depth.

The two plots, may be used for the determination of the slope of the channel and speed of the nutrient solution when depth of the nutrient solution and discharge of the pump are determined. 


\section{CONCLUSION}

- In this experiment slope of the channel of the nutrient solution and discharge of the pump were determent for the easiness of controlling of each. The depth of the nutrient solution and its speed were determined graphically in case of a non-cultivated NFT.

- It is expectable that the optimum depth of the nutrient solution when cultivating different plants under NFT will be different from that obtained by graphs (without cultivation) so the results obtained by the experiment may be looked for as a guide for suggesting the depth of the nutrient solution for different plants based on the experience with the type of cultivation and we recall that the range of depth of the nutrient solution obtund from the experiment $(0.8-3.2 \mathrm{~mm})$ approaches that given by Graves and Hurd 1983 (1-3mm).

- A guide for suggesting the optimal depth of cultivation under NFT may be as follows:

(1) Recall that the tests were carried out on an experimental Nutrient-Film system (suitable for experimental growth chamber), so we determine slope and speed for a channel of width of $28 \mathrm{~cm}$ and length of one meter.

(2) We look for range of depth obtained by graphs $(0.8-3.2 \mathrm{~mm})$ as well as experience with the cultivated plant to suggest the depth of the nutrient solution.

(3) We chose the discharge either according to the experience with the cultivated crop under NFT , hence we must choose one of the three tested discharges: $1.75,2.25$ and $4.6 \mathrm{~L} / \mathrm{min}$ or we may chose the least tested discharge in this study: $1.75 \mathrm{~L} / \mathrm{min}$.

(4) According to the suggested depth and discharge, we determine the slope of the channel from Fig.(2) and we determine the speed from Fig.(3).

(5) This research needs subsequent experiments on which the procedure of this research may be applied at cultivation of deferent plants under NFT. 


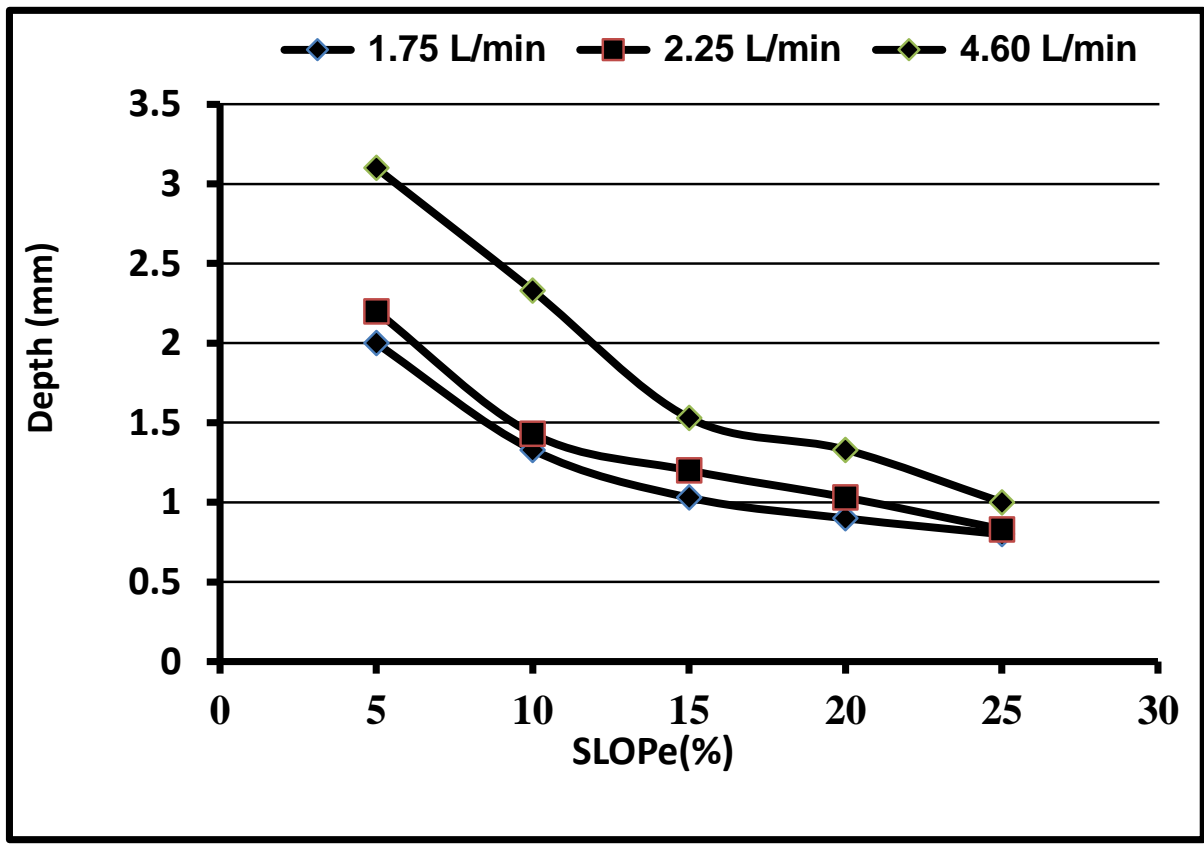

Fig.(2):The relationship between the slope of the channel and the depth of the nutrient solution under the $r$ three tested discharges.

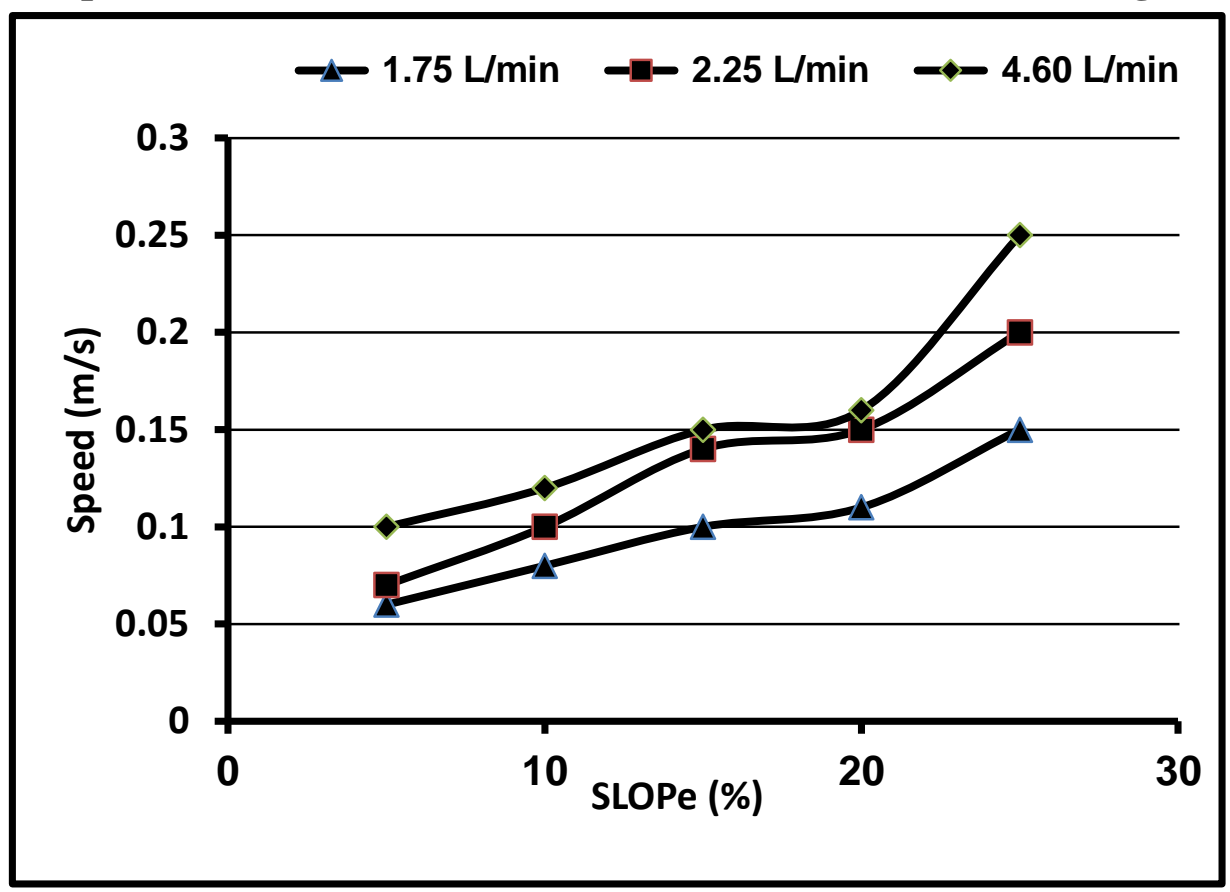

Fig.(3): The relationship between the slope of the channel and the speed of the nutrient solution under the three tested discharges. 


\section{SUMMARY}

This study aims to getting experimental graphical relations (empirical graphs) that relate the main factors affecting the Nutrient-Film Technique "NFT" by using a small NFT unit suitable for carrying out experiments on different plants.

The studied factors were: depth of the nutrient solution and speed of the nutrient solution, slope of the channel of the nutrient solution and discharge of the feeding pump.

Slope of the channel and discharge of the pump were taken as variables. Values of the slope of the channel were: 5, 10, 15, 20 and $25 \%$ and values of the discharge were: $1.75,2.25$ and $4.6 \mathrm{~L} / \mathrm{min}$.

Each of depth of the nutrient solution and speed of the nutrient solution were measured at each discharge and its corresponding slope.

The study showed that: at all the tested discharges, as the slope increases, the depth of the nutrient solution decreases and the speed of the nutrient solution increases.

Curves may enable the determination of each of the depth of the nutrient solution and speed of the nutrient solution under the following conditions: Curves may enable the determination of each of the depth of the nutrient solution and speed of the nutrient solution under the following conditions:

1- The study was carried out without cultivation.

2- Length of the channel of the nutrient solution is $1 \mathrm{~m}$ and its width is $28 \mathrm{~cm}$.

3- Choosing a depth of the nutrient solution from the range obtained by the experiment $(0.8-3.2 \mathrm{~mm})$ and as this range was obtained from a non-cultivated NFT so experience with the cultivated plant must be taken into consideration to suggest a depth of nutrient solution for a certain plant.

4- Choosing either of the three discharges: $1.75,2.25$ and $4.6 \mathrm{~L} / \mathrm{min}$.

5- Knowing depth and discharge, each of slope of channel and speed of the nutrient solution can be determined graphically.

6- This research needs subsequent experiments on which the procedure of this research may be applied at cultivation of deferent plants under NFT. 


\section{REFERANCES}

Carly M. (2011). Leafy Asian vegetables and their nutrition in hydroponics. Industry \& Investment NSW., ISBN 978174256077 9,(24): 7.

Cooper A. (1996). The ABC of NFT. 2ed. Grower Books, London, UK: 20.

Graves C. J. and R.G. Hurd (1983) .intermittent solution circulation in the nutrient film technique Acta hortic.133:47-52.

Jenner G. and N. Starkey (1980). Nutrient Film Technique practicalities of cadmium plant soil 49:333-342.

Lynette M. (1999). Nutrient Film Technique (NFT) Production of Lettuce. Source. Available from: URL [http:www.cropking.com/NFT lettuce 1 .shtm1]:1-3.

Soo-Hyung K., R. R. Vangimalla, T. B. Jeffrey, C. G. Dennis and J. T. Dennis (2004). Quantification of photosynthetically active radiation inside sunlit growth chambers. Agricultural and Forest Meteorology $126: 117-127$.

Spensley k., G. M. Winsor and A.J. Cooper(1979). Nutrient Film Technique-crop culture in flowing nutrient solution outlook on agriculture 9:299-305.

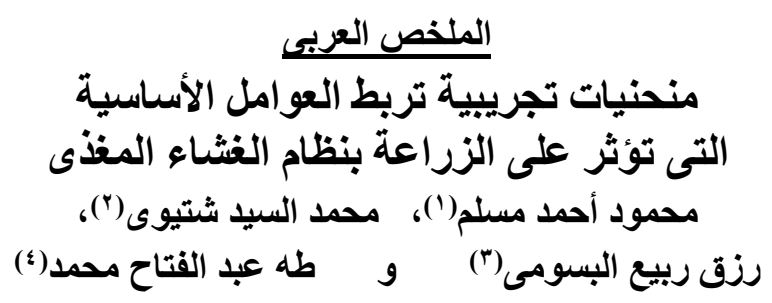

تهدف هذه الدراسة إلى الحصول على علاقات بيانية تجرييية empirical تربط بين العوامل

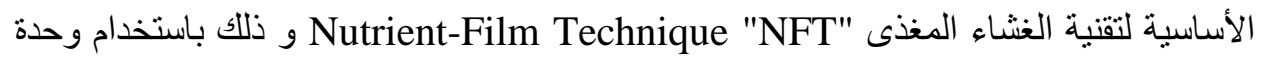
صغيرة الحجم تصلح لإجراء التجارب على النباتات المختلفة وقد اجريت هذه التجربة ولفاء

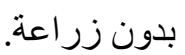
العو امل التى دُرست هى: عمق محلول التغذية و سرعة جريانه و ميل قناة المحلول المغذى و تصرف طلمبة التغذية.

\footnotetext{
(1) (1) أستاذ - كلية الهندسة الزراعية بالقاهرة - جامعة الأزهر.

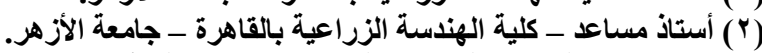

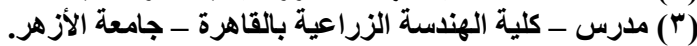

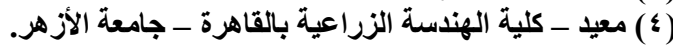




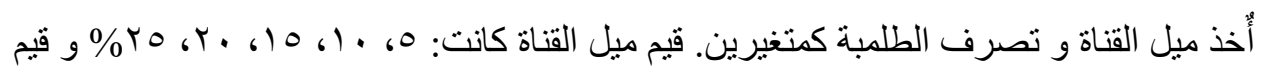

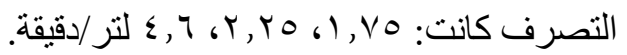
تم قياس عمق المحلول المغذى و سر عة جريانه عند كل تصرف مع الميل المناظر. بينت هذه الدراسة أنه عند كل التصرفات المستخدمة فإنه بزيادة الميل يقل عمق المحلول المغذى لهن و تزيد سرعة جريانه. رُسمت مجمو عتين من المنحنيات قد يمكن استخدامها لاستتناج كل من عمث المحلول المغذى و و

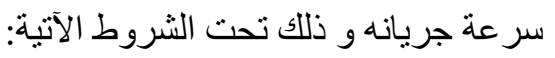
اــ تمت الدراسة بدون زر اعة نبات على وحدة الغشاء المغذى.

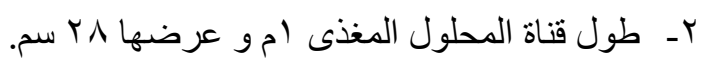

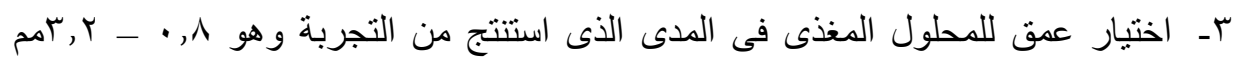

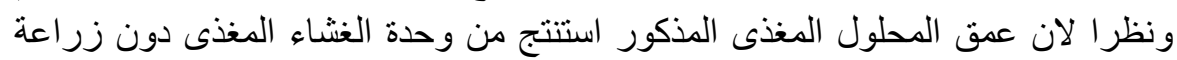

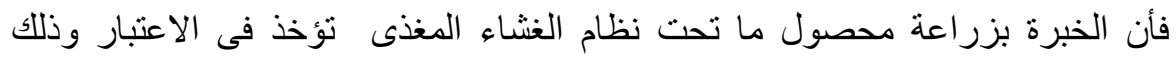
لاقتر اح عمق مناسب.

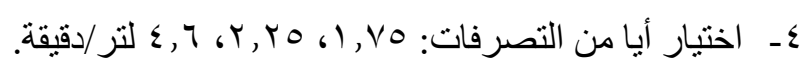

هــ بناءً على العمق و التصرف يمكن استتناج ميل القناة وسر عة جريان المحلول المغذى بيانيا. 7- يحتاج هذا البحث الى در اسات نالية قد تطبق منهجه مع زر اعة نباتات مختلفة. 